\title{
PENGARUH EKSTRAK METANOL DAUN PEPAYA (Carica papaya L.) TERHADAP AKTIVITAS ENZIM LIPASE
}

\section{[The Effects of Methanol Extract of Leaves Papaya (Carica papaya L.) Against Lipase Enzyme Activity]}

\author{
Nurhaeni ${ }^{1}$, Ahmad Ridhay ${ }^{1}$, Magfira $^{1 *}$ \\ 1 Jurusan Kimia Fakultas MIPA, Universitas Tadulako \\ JI. Soekarno Hatta Km.9, Kampus Bumi Tadulako Tondo Palu, Telp. 0451- 422611
}

*)Coresponding author: magfirahalmin99@gmail.com

Diterima 21 Juni 2017, Disetujui 30 Agustus 2017

\begin{abstract}
Has conducted research on the effects of methanol extract of leaves papaya (Carica papaya L.) Against Lipase Enzyme Activity. This study aimed to obtain information in a methanol extract inhibits lipase activity. The method used is Complete Random Design (RAL), with goal attainment is done by determining the incubation time lipase enzyme, $\mathrm{pH}$ optimum lipase enzyme, and maximum substrate concentration lipase enzyme. And determining the effect of the methanol extract to inhibit the lipase enzyme activity. The results showed that the best incubation time of lipase obtained by time of 120 minutes, the optimum $\mathrm{pH} 7$ and the maximum substrate concentration of $4 \%$. With the highest activity were obtained $16.94 \mathrm{~mol} / \mathrm{ml}$.menit, $13.33 \mathrm{~mol} / \mathrm{ml}$.menit, and $12.89 \mathrm{~mol} / \mathrm{ml}$.menit. The methanol extract of papaya leaves can inhibit the lipase enzyme activity the best concentration of $2 \%$ with the acquisition activity of $3.67 \mathrm{~mol} / \mathrm{ml}$.menit.
\end{abstract}

Keyword: papaya, lipase, incubation time, optimum $\mathrm{pH}$, substrate concentration.

\begin{abstract}
ABSTRAK
Telah dilakukan penelitian tentang pengaruh Ekstrak Metanol Daun Pepaya (Carica papaya L.) Terhadap Aktivitas Enzim Lipase. Penelitian ini bertujuan untuk mendapatkan keterangan ekstrak metanol dalam menghambat aktivitas enzim lipase. Metode yang digunakan adalah Rancangan Acak Lengkap (RAL), dengan pencapaian tujuan dilakukan melalui penentuan waktu inkubasi enzim lipase, $\mathrm{pH}$ optimum enzim lipase dan konsentrasi substrat maksimum enzim lipase. Serta penentuan pengaruh ekstrak metanol dalam menghambat aktivitas enzim lipase. Hasil menunjukkan bahwa waktu inkubasi terbaik enzim lipase diperoleh dengan waktu 120 menit, $\mathrm{pH}$ optimum 7 dan konsentrasi substrat maksimum 4\%. Dengan aktivitas tertinggi masing-masing diperoleh 16,94 $\mu \mathrm{mol} / \mathrm{ml}$.menit, $13,33 \mu \mathrm{mol} / \mathrm{ml}$.menit, dan 12,89 $\mu \mathrm{mol} / \mathrm{ml}$.menit. Ekstrak metanol daun papaya dapat menghambat aktivitas enzim lipase pada konsentrasi terbaik $2 \%$ dengan perolehan aktivitas sebesar $3,67 \mu \mathrm{mol} / \mathrm{ml}$.menit.
\end{abstract}

Kata kunci : papaya, lipase, waktu inkubasi, pH optimum, konsentrasi substrat 


\section{LATAR BELAKANG}

Tanaman pepaya termasuk salah satu tanaman hortikultura yang ditemukan tumbuh dengan pertumbuhan subur di daerah Lembah Palu. Disamping itu daun pepaya telah banyak dikenal masyarakat kota Palu dan keberadaannya juga mudah ditemukan. Menurut Dalimartha (2003) dalam ekstrak daun pepaya terdapat metabolit sekunder salah satunya senyawa alkaloid yang ditandai dengan rasa pahit. Akan tetapi hingga saat ini belum ada ditemukan penelitian tentang penghambatan enzim lipase oleh ekstrak dari daun pepaya. Aktivitas atau kerja enzim dipengaruhi oleh banyak faktor, seperti suhu, $\mathrm{pH}$, konsentrasi substrat, waktu inkubasi, konsentrasi enzim, inhibitor, dan pelarut organik. Kholifah (2008) yang meneliti tentang pengaruh ekstrak kasar daun dewa terhadap aktivitas lipase menghasilkan bahwa ekstrak kasar daun dewa dapat menghambat aktivitas lipase pada konsentrasi ekstrak $30 \mathrm{mg} / 10 \mathrm{ml}$ (aq) hingga $90 \mathrm{mg} / 10 \mathrm{ml}$ (aq). Kondisi ini berlangsung dengan waktu inkubasi terbaik 6 menit, konsentrasi substrat $1 \%$ dengan suasana $\mathrm{pH}$ optimum 7.

Rahardjo (2005) menyatakan bahwa ekstrak jati belanda dapat menurunkan aktivitas enzim lipase pada tikus (ratus) yang ditandai dengan penurunan berat badan secara bertahap pada tikus (ratus). Hal ini dikarenakan ekstrak daun tersebut mempunyai kandungan senyawa alkaloid yang diduga memiliki efek menghambat aktivitas enzim lipase karena mempunyai struktrur kimia yang mirip orlistat (sejenis obat).

Keberadaan enzim di dalam tubuh sangatlah penting akan tetapi jika kondisi aktivitas enzim berlebih maka akan membawa dampak negatif bagi tubuh, seperti obesitas. Publikasi penghambatan enzim lipase oleh ekstrak pepaya belum ditemukan, sehingga perlu dilakukan penelitian tentang penghambatan aktivitas enzim oleh ekstrak daun pepaya.

\section{METODE PENELITIAN}

\section{Bahan dan Peralatan}

Peralatan yang digunakan terdiri atas: Blender, ayakan 60 mesh, statif, klem, neraca analitik, rotari evaporator, frez dryer, shaker inkubator, lemari pendingin, peralatan sentrifuge, kain saring dan alat-alat gelas yang umum digunakan dalam Laboratorium kimia.

Bahan dasar yang digunakan dalam penelitian ini adalah daun pepaya muda (3 tangkai teratas) dan daun pepaya tua (3 tangkai terbawah) yang diperoleh dari Desa Dalika Kecamatan Labuan Toposo. Bahan pengekstrak : metanol teknis, heksan teknis, dan larutan $\mathrm{CaCl}_{2}$ 0,01 M. Bahan-bahan pembantu: Kloroform p.a, larutan $\mathrm{H}_{2} \mathrm{SO}_{4} 2 \mathrm{~N}$, larutan $\mathrm{NH}_{4} \mathrm{OH} 0,1 \mathrm{M}$, larutan $\mathrm{NaOH} 0,1 \mathrm{~N}$, larutan $\mathrm{H}_{2} \mathrm{C}_{2} \mathrm{O}_{4} 0,1 \mathrm{~N}$, amonium sulfat teknis (pupuk ZA), indikator pp, minyak zaitun, aquades, larutan gum arab $10 \%$, buffer fosfaat $\mathrm{pH} 6$, 7, 8, 9 dan 10 larutan fosfat 0,2 M $\left(\mathrm{Na}_{2} \mathrm{HPO}_{4}\right)$, kertas indikator, pereaksi 
dragendorf, pereaksi mayer, pereaksi wagner dan label.

\section{Prosedur Penelitian}

\section{Preparasi Sampel Daun Pepaya}

Tumbuhan daun pepaya tua diambil bagian daunnya, dibersihkan dan dikeringkan dengan cara diangin-anginkan selama 5 hari. Kemudian sampel dihancurkan dengan blender dan diayak dengan menggunakan ayakan 60 mesh untuk mendapatkan daun pepaya dalam bentuk tepung.

\section{Ekstraksi Daun Pepaya Dengan Metode Maserasi (Lusiana H., 2009)}

Daun pepaya yang telah diayak menjadi tepung ditimbang sebanyak 200 gram, kemudian diekstraksi menggunakan metode maserasi dengan menggunakan pelarut metanol pada perbandingan 1:3 (b/v) selama $3 \times 24$ jam. Setiap $1 \times 24$ jam dilakukan penyaringan. Setelah disaring, sampel dimaserasi kembali dengan metanol yang baru. Pengerjaan dilakukan sebanyak 3 kali. Selanjutnya hasil maserasi ketiganya yang diperoleh digabungkan, lalu diuapkan dengan evaporator pada suhu $40^{\circ} \mathrm{C}$. Sehingga diperoleh ekstrak metanol kental. Selanjutnya ekstrak metanol kental sebanyak $100 \mathrm{ml}$ diekstrak cair-cair dengan pelarut heksan dengan perbandingan 1:1 (v/v) sehingga diperoleh ekstrak metanol bebas minyak. Perlakuan diulang sebanyak tiga kali. Ekstrak ditimbang untuk menentukan rendemennya dengan persamaan :
Rendemen $(\%)=\frac{\text { Berat ekstrak }}{\text { Berat sampel }} \times 100 \%$

\section{Identifikasi Senyawa Alkaloid (Qurota Ayun et al., 2015)}

Sebanyak 2 gram sampel dilarutkan dalam kloroform secukupnya. Larutan kemudian ditambahkan $10 \mathrm{ml}$ amoniak dan 10 tetes $\mathrm{H}_{2} \mathrm{SO}_{4} 2 \mathrm{~N}$. Larutan kemudian dimasukkan kedalam corong pisah serta dikocok secara teratur selama beberapa menit. Kemudian didiamkan beberapa menit hingga terbentuk 2 lapisan. Lapisan atas dipindahkan kedalam 3 tabung reaksi. Ketiga larutan diuji dengan pereaksi wagner, dragendorf, dan meyer. Terbentuknya endapan menunjukkan larutan mengandung alkaloid, dimana dengan larutan wagner menghasilkan endapan berwarna coklat, pereaksi dragendorf menghasilkan endapan merah jingga dan pereaksi mayer menghasilkan endapan warna putih.

\section{Ekstraksi Enzim Lipase Dari Daun Pepaya Muda}

Enzim lipase yang digunakan diambil dari daun pepaya muda hal ini berdasarkan penelitian Ikbal (2012) yang mendapatkan pada daun pepaya muda memiliki aktivitas enzim lipase tertinggi. Tahapannya adalah: Daun pepaya muda diambil dan dipisahkan dari tangkai daunnya. Kemudian ditimbang sebanyak 500 gram dan dihancurkan dengan blender dengan menggunakan pelarut $\mathrm{CaCl}_{2} \quad 0,01 \mathrm{M}$ sebanyak $500 \mathrm{ml}$. Selanjutnya disaring dengan kain saring 
dan ditampung filtratnya. Filtrat selanjutnya disentrifuge selama 20 menit, kemudian didekantasi diruangan terbuka selama 24 jam. Hasil dekantasi kemudian disaring untuk memisahkan endapan dan filtrat. Filtrat yang diperoleh berwarna kuning.

\section{Isolasi Enzim Lipase (Ikbal, 2012)}

Isolasi lipase dari ekstrak daun pepaya muda dilakukan menggunakan metode pengendapan/koagulasi dengan bahan pengendap amonium sulfat (pupuk ZA). Ekstrak lipase dengan volume $500 \mathrm{ml}$ ditambahkan dengan amonium sulfat hingga mencapai tingkat kejenuhan $65 \%$. $\mathrm{Hal}$ ini sebagaimana penelitian ikbal (2012) yang mendapatkan rendemen dan aktivitas tertinggi enzim lipase pada tingkat kejenuhan 65\% amonium sulfat. Selanjutnya diaduk dan disimpan dalam lemari pendingin selama 24 jam. Koagulan yang terbentuk disaring secara vakum, kemudian dibekukan selama 1 hari dan di frez dryer. Sehingga diperoleh endapan enzim lipase kering yang berwarna kuning. Perlakuan diulang sebanyak tiga kali. Rendemen ditimbang dengan persamaan berikut :

$$
\text { Rendemen ekstrak (\%)= } \frac{\text { Berat enzim ekstrak }}{\text { Berat daun pepaya }} \times 100 \%
$$

\section{Penentuan Waktu Inkubasi Enzim Lipase (Kholifah, 2008)}

Kedalam labu ukur $25 \mathrm{ml}$ dimasukkan $1 \mathrm{ml}$ minyak zaitun dan $9 \mathrm{ml}$ gum arab $10 \%$ dalam air, dihomogenkan selama 2 menit. Kemudian campuran diatur pada $\mathrm{pH} 7$ dengan menambahkan 2 $\mathrm{ml}$ larutan fosfat $0,2 \mathrm{M}\left(\mathrm{Na}_{2} \mathrm{HPO}_{4}\right)$ dan 3 $\mathrm{ml}$ buffer fosfat $\mathrm{pH}$ 7. Selanjutnya campuran dijadikan tepat $25 \mathrm{ml}$.

Campuran diatas dimasukkan kedalam erlenmeyer $100 \mathrm{ml}$ untuk dijadikan substrat dan ditambahkan 0,5 gram enzim lipase. Campuran kemudian diinkubasi dalam shaker inkubator dengan variasi waktu inkubasi 30 menit, 60 menit, 90 menit dan 120 menit. Hidrolisis terjadi selama inkubasi dan dihentikan dengan menambahkan aseton : etanol (1:1) sebanyak $10 \mathrm{ml}$. Sampel hasil hidrolisis ditambahkan 3 tetes indikator pp dan dititrasi dengan $\mathrm{NaOH} 0,1 \mathrm{~N}$ hingga berwarna merah jambu yang tidak hilang selama 30 detik. Volume $\mathrm{NaOH}$ yang digunakan titrasi dicatat dan digunakan untuk menghitung aktivitas hidrolisis lipase menggunakan persamaan sebagai berikut:

Aktivitas lipase $=\frac{\text { volume } \mathrm{NaOH}(\mathrm{A}-\mathrm{B}) \times \mathrm{N} \mathrm{NaOH} \times 1000}{\text { waktu reaksi (menit) } \times \text { berat enzim }(\mathrm{g})}$

Waktu inkubasi dengan aktivitas enzim tertinggi dinyatakan sebagai waktu inkubasi terbaik untuk digunakan pada penelitian selanjutnya. Dan perlakuan diulang sebanyak tiga kali.

\section{Penentuan pH Optimum Enzim Lipase (Kholifah, 2008)}

Kedalam labu ukur $25 \mathrm{ml}$ dimasukkan $1 \mathrm{ml}$ minyak zaitun dan $9 \mathrm{ml}$ gum arab 10\% dalam air, dihomogenkan selama 2 menit. Kemudian campuran diatur pada variasi $\mathrm{pH}$ 6, 7, 8, 9 dan 10 . 
dengan menambahkan larutan fosfat 0,2 $\mathrm{M}$ dan $5 \mathrm{ml}$ buffer fosfat sesuai pHnya. Selanjutnya campuran ditepatkan $25 \mathrm{ml}$.

Campuran diatas dimasukkan kedalam erlenmeyer $100 \mathrm{ml}$ untuk dijadikan substrat dan ditambahkan 0,5 gram enzim lipase. Campuran kemudian diinkubasi dalam shaker inkubator selama waktu inkubasi terbaik. Hidrolisis terjadi selama inkubasi dan dihentikan dengan menambahkan aseton : etanol (1:1) sebanyak $10 \mathrm{ml}$. Sampel hasil hasil hidrolisis ditambahkan 3 tetes indikator pp dan dititrasi dengan $\mathrm{NaOH} \mathrm{0,1} \mathrm{N}$ hingga berwarna merah jambu yang tidak hilang selama 30 detik. Selanjutnya aktivitas hidrolisis lipase dihitung.

\section{Penentuan Konsentrasi Substrat Maksimum Enzim Lipase (Kholifah, 2008)}

Kedalam labu ukur $25 \mathrm{ml}$ dimasukkan minyak zaitun dan $9 \mathrm{ml}$ gum arab $10 \%$ dalam air, dihomogenkan selama 2 menit. Campuran diatur pada $\mathrm{pH}$ optimum dengan menambahkan larutan fosfat $0,2 \mathrm{M}\left(\mathrm{Na}_{2} \mathrm{HPO}_{4}\right)$ dan $5 \mathrm{ml}$ buffer fosfat $\mathrm{pH}$ optimum. Selanjutnya campuran dijadikan tepat $25 \mathrm{ml}$. Campuran dibuat dengan variasi konsentrasi substrat $3 \%$, $3,5 \%, 4 \%$ dan $4,5 \%$

Campuran diatas dimasukkan kedalam erlenmeyer $100 \mathrm{ml}$ untuk dijadikan substrat dan ditambahkan 0,5 gram enzim lipase. Campuran kemudian diinkubasi dalam shaker inkubator selama waktu inkubasi terbaik. Hidrolisis terjadi selama inkubasi dan dihentikan dengan menambahkan aseton : etanol (1:1) sebanyak $10 \mathrm{ml}$. Sampel hasil hasil hidrolisis ditambahkan 3 tetes indikator pp dan dititrasi dengan $\mathrm{NaOH} 0,1 \mathrm{~N}$ hingga berwarna merah jambu yang tidak hilang selama 30 detik. Selanjutnya aktivitas hidrolisis lipase dihitung.

Pengaruh Ekstrak Metanol Daun Pepaya Terhadap Aktivitas Enzim Lipase (Kholifah, 2008)

Kedalam labu ukur $25 \mathrm{ml}$ dimasukkan minyak zaitun dan ditambahkan $9 \mathrm{ml}$ gum arab 10\% dalam air, dihomogenkan selama 2 menit. Campuran diatur pada $\mathrm{pH}$ optimum dengan menambahkan larutan fosfat 0,2 $\mathrm{M}\left(\mathrm{Na}_{2} \mathrm{HPO}_{4}\right)$ dan $5 \mathrm{ml}$ buffer fosfat $\mathrm{pH}$ optimum. Selanjutnya campuran dijadikan tepat $25 \mathrm{ml}$. Campuran dibuat dengan konsentrasi substrat maksimum.

Campuran diatas dimasukkan kedalam erlenmeyer $100 \mathrm{ml}$ untuk dijadikan substrat dan ditambahkan 0,5 gram enzim lipase. Kemudian ditambahkan ekstrak metanol daun pepaya dengan variasi konsentrasi $0 \%$, $1 \%, 1,5 \%, 2 \%$ dan $2,5 \%$. Campuran kemudian diinkubasi dalam shaker inkubator selama waktu inkubasi terbaik. Hidrolisis terjadi selama inkubasi dan dihentikan dengan menambahkan aseton : etanol (1:1) sebanyak $10 \mathrm{ml}$. Sampel hasil hasil hidrolisis ditambahkan 3 tetes indikator pp dan dititrasi dengan $\mathrm{NaOH} 0,1$ $\mathrm{N}$ hingga berwarna merah jambu yang tidak hilang selama 30 detik. Selanjutnya aktivitas hidrolisis lipase dihitung. 
HASIL DAN PEMBAHASAN

\section{Ekstrak Daun Pepaya}

Pemilihan pelarut metanol pada proses ekstraksi karena metanol mampu melarutkan seluruh golongan metabolit sekunder, salah satunya senyawa alkaloid. Kemampuan pelarut metanol karena sifatnya yang tidak terlalu besar kepolarannya, sehingga mampu melarutkan baik senyawa polar, semipolar, maupun nonpolar. Pemilihan metode maserasi karena untuk menghindari kerusakan dari senyawasenyawa yang tidak tahan terhadap suhu panas. Kelebihan lain dari metode maserasi yaitu ekstrak yang didapatkan lebih banyak. Rendemen ekstrak metanol yang diperoleh adalah $22,76 \%$.

\section{Hasil Identifikasi senyawa alkaloid}

Analisis senyawa alkaloid dilakukan dengan tiga pereaksi yaitu dragendorf, wagner dan mayer.

Tabel 1. Hasil uji alkaloid

\begin{tabular}{|c|c|c|c|c|}
\hline \multirow{2}{*}{$\begin{array}{l}\text { Ekstrak } \\
\text { metanol } \\
\text { pepaya }\end{array}$} & \multicolumn{3}{|c|}{ Pereaksi dan Perubahan } & \multirow{2}{*}{$\begin{array}{c}\text { Hasil } \\
\text { Uji }\end{array}$} \\
\hline & Dragendorf & Mayer & Wagner & \\
\hline $2 \mathrm{gr}$ & $\begin{array}{c}\text { Endapan } \\
\text { merah } \\
\text { jingga }\end{array}$ & $\begin{array}{c}\text { Endapan } \\
\text { putih }\end{array}$ & $\begin{array}{c}\text { Endapan } \\
\text { coklat }\end{array}$ & + \\
\hline
\end{tabular}

Ketiga pereaksi diatas adalah pereaksi yang umum digunakan dalam mengidentifikasi senyawa alkaloid (uji kualitatif). Uji positifnya ditandai dengan terbentuknya endapan (Tabel 1). Temuan tersebut sama dengan yang ditemukan Qurrota A'yun et al., (2015) ekstrak pepaya yang dianalisis dengan tiga pereaksi di atas memberikan reaksi positif dengan terbentuknya endapan. Prinsip dari metode ini adalah reaksi pengendapan yang terjadi karena adanya pergantian ligan (Qurrota A'yun et al., 2015).

\section{Spektrum Inframerah}

Spektrum inframerah memberikan informasi terhadap gugus fungsional yang terkandung dalam struktur molekul, terutama bermanfaat dalam menetapkan jenis ikatan yang ada dalam molekul. Serapan pada 3358,66 $\mathrm{cm}^{-1}$ mengindikasikan adanya gerak ulur $\mathrm{N}-\mathrm{H}$ yang tidak muncul karena adanya serapan gugus $-\mathrm{OH}$ yang lebih kuat dibandingkan -NH (Gambar 1). Ikatan hidrogen mempunyai pengaruh pada lebarnya absorpsi infra merah yang berasal dari ikatan $\mathrm{OH}$ atau $\mathrm{NH}$ (Fessenden \&Fessenden, 1999). Absorpsi amina (NH) lebih lemah dari pada alkohol $(\mathrm{OH})$. Karena ikatan hidrogen amina lebih lemah dari pada ikatan gugus fungsi alkohol (Silverstein et al., 1984).

Serapan pada $2943 \mathrm{~cm}^{-1}$ dan 2839 $\mathrm{cm}^{-1}$ diduga merupakan serapan dari $\mathrm{CH}_{3}$ stretch. Serapan pada 816,09 $\mathrm{cm}^{-1}$ merupakan serapan dari gugus $\mathrm{CN}$ stretch. Gugus $\mathrm{C}=\mathrm{C}$ teridentifikasi pada serapan $16646,59 \mathrm{~cm}^{-1}$ dan $1522,31 \mathrm{~cm}^{-}$ ${ }^{1}$.Gugus fungsi pendukung lain yang ditunjukkan oleh gambar spektrum inframerah adalah $\mathrm{C}-\mathrm{H}$. alifatik didaerah $1452,64 \mathrm{~cm}^{-1}$, Kibasan $\mathrm{NH}$ pada serapan 
$816,09 \mathrm{~cm}^{-1}$ dan $1409,79 \mathrm{~cm}^{-1}$ serta gugus eter C-O di daerah 1020,17 $\mathrm{cm}^{-1}$. Hasil pembacaan spektrum inframerah pada gambar 1 dikelompokkan dalam beberapa gugus fungsi yang ditampilkan pada
Tabel 2. Dari hasil yang spektrum yang diperoleh ditambah dengan uji alkaloid menggunakan pereaksi dapat dikatakan bahwa ekstrak daun pepaya mengandung alkaloid.

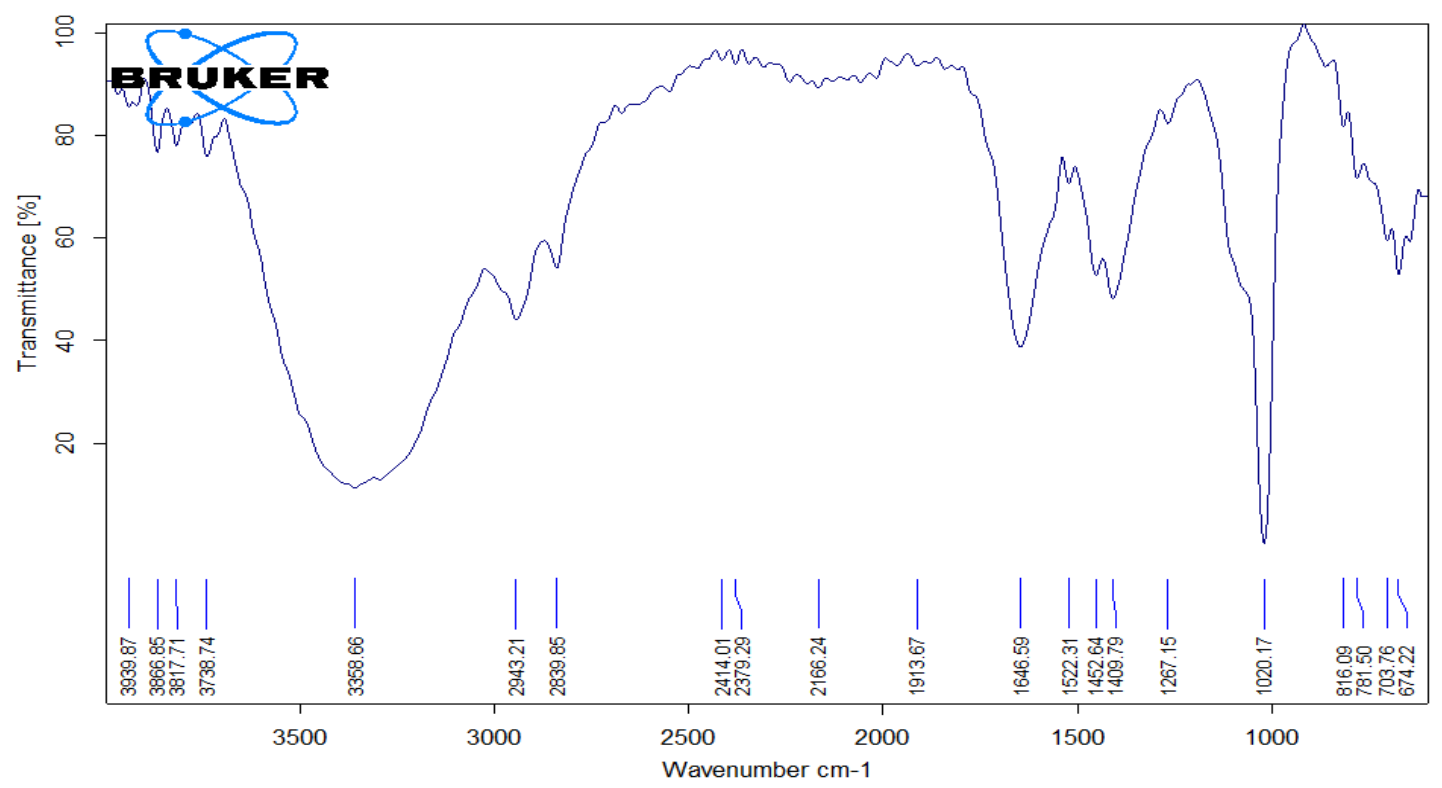

Gambar 1. Spektrum inframerah ekstrak metanol daun pepaya

Tabel 2. Interpretasi data Infra Red (IR) ekstrak alkaloid daun pepaya

\begin{tabular}{lccl}
\hline No. & $\begin{array}{c}\text { Fraksi } \\
\text { aktif } \\
\left(\mathrm{cm}^{-1}\right)\end{array}$ & $\begin{array}{c}\text { Literatur }^{*} \\
\left(\mathrm{~cm}^{-1}\right)\end{array}$ & Gugus fungsi \\
\hline 1 & 816,09 & $800-1100$ & C-N stretch \\
2 & 1522,31 & $1450-1600$ & $\mathrm{C}=\mathrm{C}$ aromatik \\
3 & 1646,59 & $1500-1675$ & $\mathrm{C}=\mathrm{C}$ \\
4 & 2943,21, & $2960-3000$ & $\mathrm{CH}_{3}$ stretch \\
5 & 2839,85 & $3000-3700$ & $\mathrm{OH}$ \\
& 3358,66 & & \\
6 & 3358,66 & $3200-3400$ & $\mathrm{~N}-\mathrm{H}$ \\
7 & 816,09 & $666-909$ & Kibasan N-H \\
8 & 1020,17 & $1000-1260$ & $\mathrm{C}-\mathrm{O}$ eter \\
9 & 2943,21 & $2700-3000$ & $\mathrm{C}-\mathrm{H}$ alifatik \\
& 2839,85 & & \\
\hline
\end{tabular}

$\left.{ }^{\star}\right)$ Sumber : Silverstein et al. (1984), Fesenden dan Fesenden (1999), Creswell et al (2005)

Isolat Enzim Lipase
Ekstraksi enzim lipase dilakukan dengan metode dekantasi diruang terbuka selama 24 jam dengan menggunakan pelarut $\mathrm{CaCl}_{2} \quad 0,01 \mathrm{M}$. Dekantasi bertujuan untuk memisahkan zat hijau daun (klorofil) pada daun pepaya. Hal ini sesuai dengan penelitian Ikbal (2012) melakukan ekstraksi enzim lipase dari daun pepaya dengan metode dekantasi diruang terbuka. Waktu dekantasi dengan aktivitas tertinggi $(5,69 \mu \mathrm{mol} / \mathrm{ml}$.menit) diperoleh pada waktu 24 jam. Menurut Aismaratu (2008) penggunaan pelarut $\mathrm{CaCl}_{2}$ 0,01 dikarenakan $\mathrm{CaCl}_{2}$ juga bisa bertindak sebagai aktivator untuk enzim lipase itu sendiri. 
Isolasi enzim lipase dilakukan dengan metode salting out, yakni menggunakan amonium sulfat teknis pada tingkat kejenuhan amonium sulfat $65 \%$. Hal ini berdasarkan dengan penelitian Ikbal (2012) yang mendapatkan rendemen dan aktivitas enzim terbaik pada tingkat kejenuhan amonium sulfat $65 \%$. Prinsip dari metode ini yaitu tingkat konsentrasi amonium sulfat akan membuat enzim keluar dari larutan membentuk koagulan. Penggunaan garam amonium sulfat karena memiliki sifat yang mudah larut dalam air serta tidak menggangu bentuk kerja enzim (Winarno, 1982). Sehingga memudahkan dalam proses isolasi enzim lipase. Rendemen enzim lipase yang diperoleh sebesar 1,069\%. Penelitian Ikbal (2012) juga mengisolasi enzim lipase daun pepaya menemukan rendemen tertinggi pada tingkat kejenuhan $65 \%$ sebesar $1,15 \%$.

\section{Waktu Inkubasi Enzim Lipase}

Waktu inkubasi aktivitas enzim lipase dilakukan dengan variasi waktu 30 menit, 60 menit, 90 menit dan 120 menit. Waktu inkubasi akan memberikan kesempatan enzim dan substrat saling kontak (proses hidrolisis) membentuk kompleks enzimsubstrat.

Hasil pengamatan aktivitas enzim lipase yang didapatkan (Gambar 2) menunjukkan aktivitas tertinggi (16,94 $\mu \mathrm{mol} / \mathrm{ml}$.menit) ditemukan pada waktu inkubasi 120 menit (2 jam). Hal demikian menunjukkan bahwa waktu inkubasi berpengaruh terhadap aktivitas enzim. Semakin lama waktu inkubasi maka akan semakin tinggi aktivitas enzim lipase yang diperoleh.

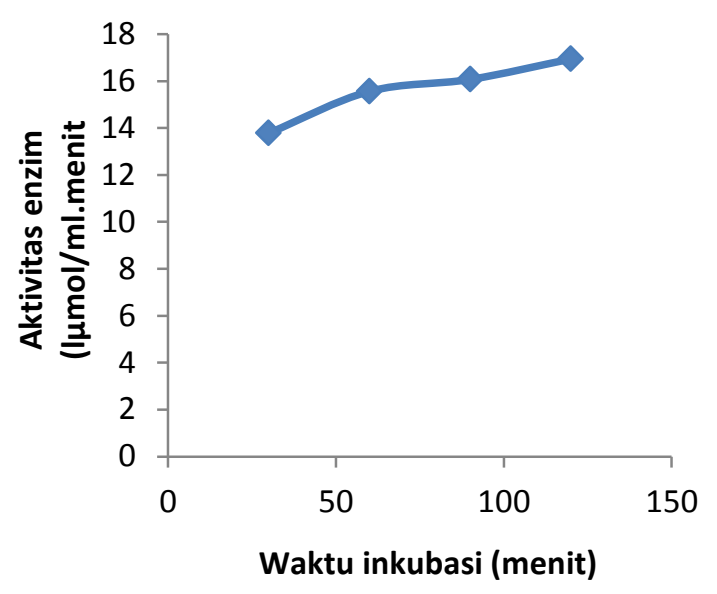

Gambar 2. Hubungan aktivitas enzim lipase terhadap waktu inkubasi (menit)

Gambar 2 menunjukkan waktu inkubasi 120 menit merupakan waktu inkubasi terbaik enzim lipase. Hal ini sesuai dengan penelitian Ikbal (2012) yang menggunakan waktu 2 jam dalam menghidrolisis enzim lipase pada daun pepaya muda.

\section{pH Optimum Enzim Lipase}

Aktivitas enzim lipase dilakukan dengan variasi $\mathrm{pH}$ yaitu $\mathrm{pH} 6,7,8,9$ dan 10. Hasil pengamatan aktivitas enzim lipase yang didapatkan (gambar 3) menunjukkan aktivitas tertinggi (13,33 $\mu \mathrm{mol} / \mathrm{ml}$.menit) ditemukan pada $\mathrm{pH} 7$ dan aktivitas terendah $(5,44$ $\mu \mathrm{mol} / \mathrm{ml}$.menit) ditemukan pada $\mathrm{pH} 10$. Aktivitas tertinggi menunjukkan kondisi 
optimum enzim lipase berada pada $\mathrm{pH}$ 7.

Hasil yang sama juga dilaporkan pada penelitian Sri Wahyu Murni et al., (2011), dimana aktivitas enzim lipase optimum dari Apergilus niger berada pada $\mathrm{pH} 7$ dengan aktivitas sebesar 1,5 $\mu \mathrm{mol} / \mathrm{ml}$.menit. Penelitan Ari Asnani \& Puji (2009) menemukan aktivitas lipase dari cacing peryonix excavatus (fraksi $70 \%$ ) tertinggi pada $\mathrm{pH} 7$, dengan aktivitas sebesar 1.050 unit/ml.

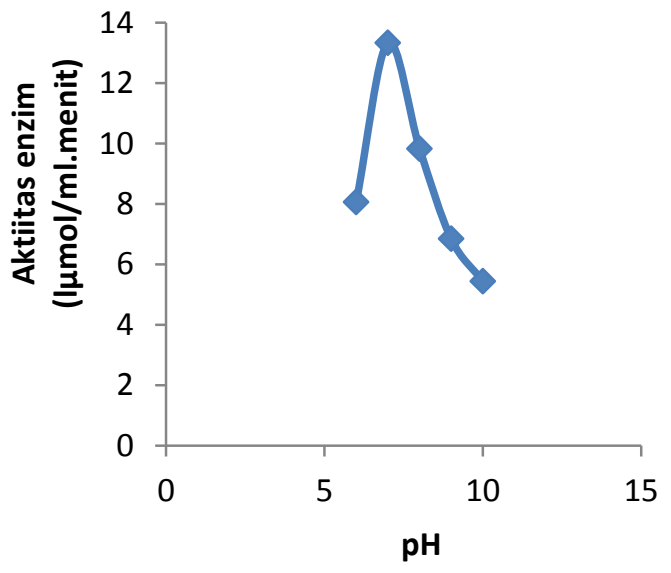

Gambar 3. Pengaruh $\mathrm{pH}$ terhadap aktivitas enzim lipase

Menurut Christakopoulus (1992) pada kondisi $\mathrm{pH}$ tinggi atau rendah memungkinkan terjadinya denaturasi dan ini mengakibatkan menurunnya aktivitas enzim. Karena enzim merupakan protein, perubahan $\mathrm{pH}$ akan menyebabkan ionisasi pada molekul protein berubah pula. Perubahan ini akan mengakibatkan struktur tiga dimensi berubah, sehingga fungsi katalitiknya terganggu. Hal tersebut dapat dilihat dari grafik dibawah ini. Pada
$\mathrm{pH}$ 8-10 aktivitas enzim semakin menurun, dan aktivitas enzim pada $\mathrm{pH}$ 6 masih menunjukkan aktivitas lebih rendah dibanding pada $\mathrm{pH} 7$.

\section{Konsentrasi Substrat Maksimum Enzim lipase}

Penentuan konsentrasi substrat terbaik, dilakukan dengan variasi konsentrasi substrat 3\%, 3,5\%, 4\%, dan $4,5 \%$. Substrat yang digunakan adalah minyak zaitun. Hasil pengamatan aktivitas enzim lipase yang didapatkan (gambar 3) menunjukkan aktivitas tertinggi $\quad(12,89 \quad \mu \mathrm{mol} / \mathrm{ml}$.menit $)$ ditemukan pada konsentrasi substrat 4 $\%$ dan aktivitas terendah $(7,61$ $\mu \mathrm{mol} / \mathrm{ml}$.menit) ditemukan pada konsentrasi substrat $3 \%$

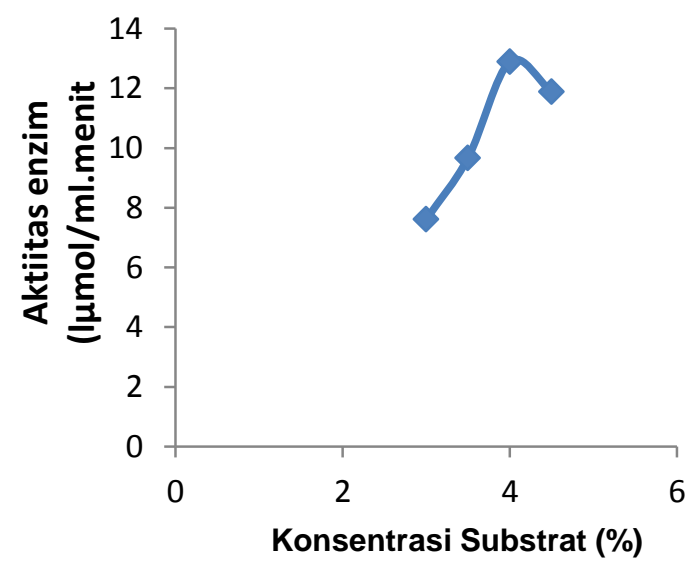

Gambar 4. Hubungan aktivitas enzim lipase terhadap konsentrasi substrat (\%)

Gambar 4 menunjukkan bahwa aktivitas tertinggi $(12,89 \mu \mathrm{mol} / \mathrm{ml}$.menit) yang ditemukan pada konsentrasi substrat $4 \%$ merupakan kondisi terbaik enzim lipase.(konsentrasi substrat maksimu) Kemudian aktivitas enzim 
perlahan menurun menjadi 11,89 $\mu \mathrm{mol} / \mathrm{ml}$.menit. Menurut Poedjiadi (1994) hal ini menunjukkan seluruh substrat sudah terhidrolisis menjadi asam lemak, sehingga tidak ada lagi kontak antara enzim dengan substrat membentuk kompleks enzim-substrat.

Penurunan aktivitas

enzim kemungkinan disebabkan oleh tingginya konsentrasi substrat yang bisa berefek menghambat (inhibitor) aktivitas enzim lipase.

\section{Pengaruh ekstrak metanol daun pepaya terhadap aktivitas enzim lipase.}

Esktrak metanol daun pepaya digunakan dalam menghambat aktivitas enzim lipase. Penelitian Kholifah (2008) menunjukkan bahwa ekstrak metanol daun dewa dapat menghambat kerja enzim lipase. Hal ini juga didukung oleh penelitian Lusiana H., (2008) yang menemukan bahwa ekstrak kasar dari akar Albertisia papuana Becc mampu menghambat pertumbuhan skizon $P$. Fulciparum.

Pengaruh konsentrasi ekstrak metanol daun pepaya dilakukan dengan variasi konsentrasi $0 \%, 1 \%, 1,5 \%, 2 \%$ dan $2,5 \%$ Hasil pengamatan menunjukkan aktivitas enzim lipase mengalami penghambatan pada konsentrasi 1\%-2,5\% ekstrak metanol. Grafik dibawah ini menunjukkan hubungan antara aktivitas enzim lipase terhadap ekstrak metanol daun pepaya.

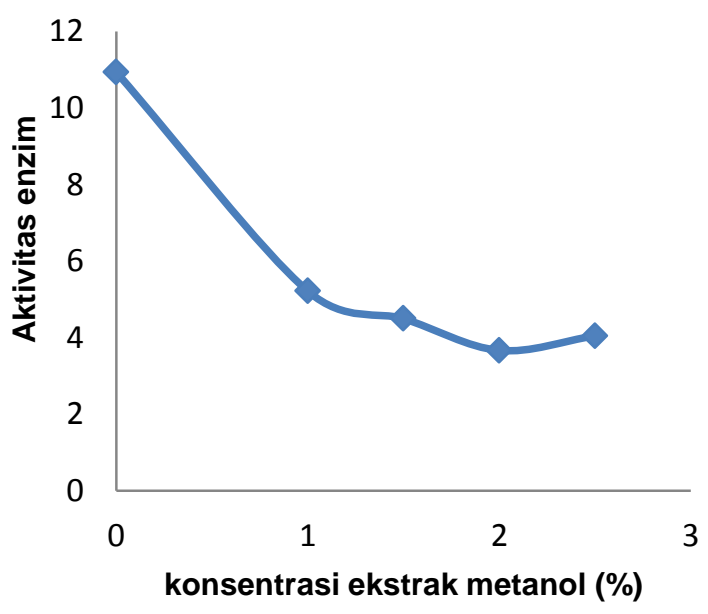

Gambar 5. Hubungan aktivitas enzim lipase terhadap konsentrasi ekstrak metanol (\%)

Berdasarkan grafik diatas pada konsentrasi ekstrak metanol 1\%-2,5\% perlahan aktivitas enzim menurun. Hal ini menunjukkan bahwa ekstrak metanol daun pepaya mampu menginhibisi aktivitas enzim lipase pada berbagai konsentrasi. Konsentrasi terbaik ditunjukkan pada konsentrasi $2 \%$. Penghambatan kemungkinan disebabkan oleh adanya senyawa alkaloid yang terdapat dalam ekstak pepaya. Selain itu kemungkinan adanya pemakaian pelarut metanol pada esktrak pepaya telah merusak enzim sehingga aktivitasnya menurun. Hal ini sebagaimana diungkapkan oleh Suhartono (1989) bahwa enzim akan hilang kestabilannya pada lingkungan pelarut organik seperti metanol.

\section{KESIMPULAN}

Aktivitas enzim lipase terbaik diidapatkan pada waktu inkubasi 120 
menit $(16,94 \mu \mathrm{mol} / \mathrm{ml}$.menit), $\quad \mathrm{pH} 7$ (13,33 $\mu \mathrm{mol} / \mathrm{ml}$.menit) dan konsentrasi substrat $4 \%(12,89 \mu \mathrm{mol} / \mathrm{ml}$.menit $)$ dan ekstrak metanol daun pepaya dapat menghambat aktivitas enzim lipase pada konsentrasi terbaik $2 \%$ dengan aktivitas terendah sebesar 3,67 $\mu \mathrm{mol} / \mathrm{ml}$.menit.

\section{UCAPAN TERIMA KASIH}

Secara khusus
menyampaikan ucapan terima kasih
kepada Laboran Jurusan Kimia dan
Himpunan Mahasiswa Kimia (HIMAKIM)
FMIPA UNTAD.

\section{DAFTAR PUSTAKA}

Aismaratu. 2008. Kajian Sifat Kespesifikan Lipase Daun Pepaya (Carica papaya L.) Dari Berbagai Varietas. (Skripsi). Palu: Universitas Tadulako.

Asnani A., Puji L. 2009. Aktivitas Amilase, Lipase dan Protease dari Cacing Peryonix excavatus. Molekul. 4(2): 115-121.

Christakopoulus, P. 1992. Production and Characterization of Extracelluler Lipase From Calvatia gigantea. Appl Microbiol Biotecnol. 38(2): 194-197.

Creswell CJ., Olaf A. Rinquist, Malcolm M. Campbel. 2005. Analisis Spektrum Senyawa Organik. Bandung: ITB.

Dalimartha, S. 2006. 36 Resep Obat Untuk Menurunkan Kolesterol. Penebar Jakarta: Swadaya.
Fesenden RJ, Fesenden JS. 1999. Kimia Organik Jilid I. Terjemahan Aloysius Hadyana Pudjaatmaka. Jakarta: Erlangga.

Harborne, J.B. 1996. Metode Fitokimia Penuntun Cara Modern Menganalisis Tumbuhan. Bandung: ITB.

Lusiana, H. 2009. Isolasi dan Uji Anti Plasmodium Secara In Vitro Senyawa Alkaloid Dari Albertisia papuana BECC. (Tesis). Bogor: Sekolah Pascasarjana IPB.

Ikbal M. 2012. Isolasi Lipase dari Daun Pepaya Varietas Lokal (Carica papaya L) dan Aplikasinya dalam Biosintesis Monolaurin. (Skripsi). Jurusan Kimia. FMIPA UNTAD. Palu.

Kholifah N. 2008. Pengaruh Ekstrak Alkaloid dari Daun Dewa (Gynura pseudo-cina (L)(DC)) Terhadap Aktivitas Enzim Lipase. (Skripsi). Jurusan Kimia Fakultas Sains dan Teknologi.Universitas Negeri Malang. Malang.

Murni SW., Kholisah SD., DL. Tanti, EM Petrissia. 2011. Produksi, Kerakterisasi dan Isolasi Lipase dari Apergilus niger. Prosiding Seminar Nasional Teknik Kimia "Kejuangan". Pengembangan Teknologi Kimia untuk Pengolahan Sumber Daya Alam Indonesia Yogyakarta, 22 Februari 2011. HIm A08-1 - A08-7.

Poedjiadi, A. 1994. Dasar-Dasar Biokimia. Jakarta: UI-Press.

Qurrota A'yun et al. 2015. Analisis Fitokimia Daun Pepaya (Carica papaya L) Dibalai Penelitian Tanaman Aneka Kacang dan Umbi 
Kendalpayak. Prosiding Seminar

Nasional Konservasi dan

Pemanfaatan Sumber Daya Alam

2015. Pendidikan Biologi,

Pendidikan Geografi, Pendidikan

Sains, PKLH - FKIP UNS.

Surakarta, 13 Januari 2015. HIm 134-137.

Rahardjo., S.S. 2005. Influen Of Etanol Extract Of Jati Belanda Leaves On Lipase Enzym Activity Of Rattus Norvegitus Serum. Inovasi. 4(17):48-53.

Silverstein RM., Bassler, G. Clayton, Terence C. Morrill. 1984. Penyidik Spektrometrik Senyawa Organik. Edisi Keempat. Terjemahan Hartomo A.J., Anny Victor Purba. Jakarta: Erlangga.

Suhartono M.T. 1989. Enzim dan Bioteknologi. Bogor: Departemen Pendidikan dan Kebudayaan, Direktorat Jenderal Pendidikan Tinggi Antar Universitas Bioteknologi, Institut Pertanian Bogor. 